Note

\title{
Cereus jamacaru seed germination and initial seedling establishment as a function of light and temperature conditions
}

\author{
Nara Lídia Mendes Alencar ${ }^{1}$, Enéas Gomes-Filho ${ }^{1,2 *}$, Renato Innecco ${ }^{3}$
}

'Universidade Federal do Ceará/CC - Depto. de Bioquímica e Biologia Molecular, C.P. 6039 - 60440-970 - Fortaleza, CE - Brasil.

2Instituto Nacional de Ciência e Tecnologia em Salinidade (INCTSal)/CC - Depto. de Bioquímica e Biologia Molecular. 3Universidade Federal do Ceará/CCA - Depto. de Fitotecnia, C.P. 12168 - 60356-001 - Fortaleza, CE - Brasil.

*Corresponding author <egomesf@ufc.br>

Edited by: Eros Artur Bohac Francisco / Daniel Scherer de Moura

Received September 09, 2010

Accepted July 22, 2011
ABSTRACT: Cereus jamacaru is a widespread Cactaceae of northeast Brazil, largely used as cattle food, and as ornamental and medicinal plant. Despite its distinguished importance, until now, there has been little information about the physiological aspects involved on its germination. The objective of this study was to evaluate the effect of light and temperature interaction on the seed germination and seedling establishment of this plant. The evaluated variables were germination percentage at 7 (\% G7) and at 14 days after imbibition (\% G14), germination average time index (GSI), germination average time (GAT), germination accumulated frequency (GAF), seedling dry mass and height. The highest \% G14 and GSI were at $25{ }^{\circ} \mathrm{C}$ in white light, whereas the highest GAT values were in darkness for all evaluated temperatures. On the other hand, \% G14, GSI and GAF had the lowest values in darkness. Seeds germinated even in darkness, being however stimulated by the presence of light. The combination of white light and temperature of 25 or $30^{\circ} \mathrm{C}$ is the most appropriate condition for seed germination tests.

Keywords: cactus seed, germination percentage, mandacaru, photoblastism

\section{Introduction}

Water, temperature, light, and salinity interact at the soil interface and regulate seed germination in arid environments (Bewley and Black, 1994; Bewley, 1997). Light is one of the most important environmental factors regulating plant growth, especially the seed germination of arid and semiarid species, among which many are positively photoblastic (Kigel, 1995). Regarding Cactaceae species, seeds of globose (i.e. Opuntia tomentosa) and barrel cacti (i.e. Ferocactus spp.) are positively photoblastic, whereas those of columnar cacti (i.e.Pachycereus pringlei and Carnegiea gigantea) are either indifferent to light or positively photoblastic (Rojas-Aréchiga and VázquezYanes, 2000; Benítez-Rodrígues et al., 2004; Ortega-Baes and Rojas-Aréchiga, 2007). Cactus seeds can germinate over a wide range of temperatures and are frequently indifferent to temperature fluctuations (Benítez-Rodrígues et al., 2004). On the other hand, some cactus seeds reach their maximum germination at constant temperatures, between 20 and $30{ }^{\circ} \mathrm{C}$, with optimal values frequently at $25{ }^{\circ} \mathrm{C}$ and with a low percentage at extreme temperatures (Rojas-Aréchiga and Vásquez-Yanez, 2000; OrtegaBaes and Rojas-Aréchiga, 2007).

One of the most representative species of the Caatinga vegetation in Brazil is the columnar cactus Cereus jamacaru DC. ssp. jamacaru. (mandacaru), which is widely distributed in this region and has great importance for sustainable development and conservation of the biodiversity of this biome. This cactus is much used during the driest months as cattle food (Cavalcanti and Resende, 2004). It is also used as an ornamental plant, and infusions/extracts of their stems and roots are claimed to be efficient for treating respiratory diseases (Andrade et al., 2006; Lorenzi and Matos, 2002). Despite of the extensive literature on the characteristics of seed germination and reproductive biology of other cactus seeds, there is little information available on C. jamacaru seed germination. Thus, we aimed to evaluate the light and temperature influence on seed germination and seedling establishment of this cactus.

\section{Materials and Methods}

Seeds were obtained from mature fruits of Cereus jamacaru D.C. plants from Crateús, state of Ceará, Brazil

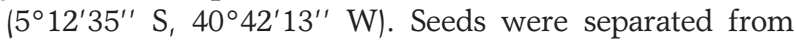
fruits, dried at ambient temperature in the shade and immediately used for the experiments. Thereafter, seeds were treated with $5 \%$ sodium hypochlorite for $5 \mathrm{~min}$, and germinated on two paper sheets moistened with distilled water $(4.5 \mathrm{~mL})$ in plastic boxes $(14 \times 14 \times 3.5 \mathrm{~cm})$ and kept in a germination chamber with a $12 \mathrm{~h}$ constant photoperiod.

$C$. jamacaru germination was analyzed under four light treatments (white, darkness, red and far-red) at six temperatures: 15, 20, 20-30 (alternated), 25, 30 and 35 ${ }^{\circ} \mathrm{C}$. White light was obtained with the aid of four daylight fluorescent lamps of $20 \mathrm{~W}$. The darkness condition was obtained by covering the plastic boxes with two sheets of aluminum foil. Red light was obtained from the white light that passed through two red cellophane papers wrapping the plastic boxes (Freitas and Takaki, 2000; Khera and Singh, 2005). The different temperatures were obtained by regulating the growth chamber.

Seeds were considered germinated after radicle protrusion (Bewley and Black, 1994). Seed germination was scored daily and under darkness condition seeds were 
monitored under a green safe light. The germination parameters recorded were: germination speed index (GSI) according to Maguire (1962), germination percentage of seeds at 7 (\% G7) and 14 days after imbibition (DAI) (\% G14) and germination average time (GAT) according to Laboriau (1983). The germination accumulated frequency (GAF) was estimated using the sum of seeds germinated daily (Laboriau and Agudo, 1987). The evaluated growth parameters were seedling average height, measured with millimeter rule and seedling dry mass (determined after plant material reached a constant weight in an oven at $60^{\circ} \mathrm{C}$ ).

Experimental design was a completely random 3 $\times 6$ factorial arrangement, corresponding to three light conditions at six temperatures, with four replicates of 50 seeds each. The temperatures of 15 and $35^{\circ} \mathrm{C}$ were not subjected to statistical analysis, because under these conditions there was no germination. The germination percentage data were arcsine-square root transformed to normalize data for ANOVA. Means were compared using a Tukey test $(p \leq 0.01)$.

\section{Results and Discussion}

C. jamacaru seed germination was $(p \leq 0.01)$ affected by the interaction between light and temperature, and germination was observed in all evaluated conditions (Table 1), except at 15 and $35^{\circ} \mathrm{C}$, with no germina-

Table 1 - Germination percentage of seeds at 14 (A) and 7 days after imbibition (DAl) (B) and germination speed index (C) of $C$. jamacaru seeds at $20,20-30{ }^{\circ} \mathrm{C}$ (alternated), 25 and $30{ }^{\circ} \mathrm{C}$ in white, darkness and red light.

\begin{tabular}{|c|c|c|c|}
\hline \multicolumn{4}{|c|}{ Germination percentage (\%) at 14 DAI (A) } \\
\hline \multirow[b]{2}{*}{ Temperatures } & \multicolumn{3}{|c|}{ Light conditions } \\
\hline & White & Darkness & Red \\
\hline \multicolumn{4}{|l|}{${ }^{\circ} \mathrm{C}$} \\
\hline 20 & 98 aA & $72 \mathrm{aB}$ & $100 \mathrm{aA}$ \\
\hline $20-30$ & $74 \mathrm{cA}$ & $67 \mathrm{aA}$ & $76 \mathrm{dA}$ \\
\hline 25 & $97 \mathrm{aA}$ & $67 \mathrm{aB}$ & $97 \mathrm{bA}$ \\
\hline 30 & $91 \mathrm{bA}$ & $10 \mathrm{bC}$ & $89 \mathrm{cA}$ \\
\hline \multicolumn{4}{|c|}{ Germination percentage (\%) at $7 \mathrm{DAl}(\mathrm{B})$} \\
\hline & \multicolumn{3}{|c|}{ Light conditions } \\
\hline Temperatures & White & Darkness & Red \\
\hline \multicolumn{4}{|l|}{${ }^{\circ} \mathrm{C}$} \\
\hline 20 & $17 \mathrm{CAB}$ & $9 \mathrm{bcB}$ & $34 \mathrm{bA}$ \\
\hline 20-30 & $61 \mathrm{bA}$ & $29 a b B$ & $37 \mathrm{bB}$ \\
\hline 25 & $90 \mathrm{aA}$ & $27 \mathrm{aB}$ & $93 \mathrm{aA}$ \\
\hline 30 & $90 \mathrm{aA}$ & $9 \mathrm{abcC}$ & 79 aA \\
\hline \multicolumn{4}{|c|}{ Germination speed index (C) } \\
\hline & \multicolumn{3}{|c|}{ Light conditions } \\
\hline Temperatures & White & Darkness & Red \\
\hline${ }^{\circ} \mathrm{C}$ & & & \\
\hline 20 & $5.8 \mathrm{cA}$ & $3.5 \mathrm{bB}$ & $6.3 \mathrm{bcA}$ \\
\hline $20-30$ & $8.2 \mathrm{bA}$ & $4.8 \mathrm{aB}$ & $5.8 \mathrm{cB}$ \\
\hline 25 & $11.0 \mathrm{aA}$ & $4.6 \mathrm{abC}$ & $8.5 \mathrm{aB}$ \\
\hline 30 & $10.1 \mathrm{aA}$ & $0.8 \mathrm{cD}$ & $7.4 \mathrm{abB}$ \\
\hline
\end{tabular}

Means followed by the same capital letters within each temperature and with the same lowercase letters within each light treatment are not different (Tukey test, $p>0.01$ ). tion (data not shown). The germination percentage at 14 DAI (\% G14) was similar for 20 and $25^{\circ} \mathrm{C}$ in white and red light, corresponding to the highest \% G14 values. However, in general, the lowest \% G14 values were observed at all temperature treatments in darkness, whereas the minimum germination rate occurred at $30{ }^{\circ} \mathrm{C}$ in darkness, corresponding to only $10 \%$ (Table 1A). This result indicated that $C$.jamacaru seeds are strongly affected by the light presence, suggesting that these seeds are positively stimulated by this condition. In contrast, for Basella rubra seeds that were subject to different light regimes with the cellophane paper use, it was not detected differences between white and red light and darkness, being these seeds classified as neutral photoblastic (Lopes et al, 2005).

The maximum rates of $\% \mathrm{G} 7$ were observed at 25 ${ }^{\circ} \mathrm{C}$ and $30{ }^{\circ} \mathrm{C}$ in white and red light, whereas the lowest $\%$ G7 were verified at 20 and $30^{\circ} \mathrm{C}$ in darkness, corresponding to only $9 \%$ (Table $1 \mathrm{~B}$ ). These data corroborate with the \% G14 results, which showed the same tendency. The highest GSI values were verified at 25 and 30 ${ }^{\circ} \mathrm{C}$ in white light, whereas the lowest GSI values were observed in all temperature treatments in darkness. The most affected condition was at $30^{\circ} \mathrm{C}$ with GSI of 0.8 (Table 1 C). This result demonstrates that $C$.jamacaru seeds are indifferent to light quality, by the fact that germina-

Table 2 - Germination average time of seeds (A), dry mass (B) and height $(C)$ of $C$. jamacaru seedlings after 14 days of imbibition at $20,20-30$ (alternated), 25 and $30^{\circ} \mathrm{C}$ in white, darkness and red light.

\begin{tabular}{|c|c|c|c|}
\hline \multicolumn{4}{|c|}{ Germination average time (days) (A) } \\
\hline \multirow{2}{*}{ Temperatures } & \multicolumn{3}{|c|}{ Light conditions } \\
\hline & White & Darkness & Red \\
\hline \multicolumn{4}{|l|}{${ }^{\circ} \mathrm{C}$} \\
\hline 20 & $8.8 \mathrm{aB}$ & $11.3 \mathrm{aA}$ & $9.1 \mathrm{aB}$ \\
\hline $20-30$ & $5.1 \mathrm{bB}$ & $9.5 \mathrm{bA}$ & $6.3 \mathrm{bB}$ \\
\hline 25 & $4.6 \mathrm{bC}$ & $8.4 \mathrm{bA}$ & $6.2 \mathrm{bB}$ \\
\hline 30 & $4.3 \mathrm{bC}$ & $6.8 \mathrm{cA}$ & $6.4 \mathrm{bB}$ \\
\hline \multicolumn{4}{|c|}{ Seedling dry mass (mg) (B) } \\
\hline \multirow{2}{*}{ Temperatures } & \multicolumn{3}{|c|}{ Light conditions } \\
\hline & White & Darkness & Red \\
\hline \multicolumn{4}{|l|}{${ }^{\circ} \mathrm{C}$} \\
\hline 20 & $1.5 \mathrm{bA}$ & $1.1 \mathrm{bcB}$ & $1.2 \mathrm{~dB}$ \\
\hline $20-30$ & $3.3 \mathrm{aA}$ & $2.6 \mathrm{aB}$ & $3.2 \mathrm{aA}$ \\
\hline 25 & $1.6 \mathrm{bA}$ & $1.4 \mathrm{bA}$ & $1.6 \mathrm{cA}$ \\
\hline 30 & $1.6 \mathrm{bB}$ & $0.7 \mathrm{cC}$ & $2.7 \mathrm{bA}$ \\
\hline \multicolumn{4}{|c|}{ Seedling average height $(\mathrm{cm})(\mathrm{C})$} \\
\hline \multirow{2}{*}{ Temperatures } & \multicolumn{3}{|c|}{ Light conditions } \\
\hline & White & Darkness & Red \\
\hline${ }^{\circ} \mathrm{C}$ & & & \\
\hline 20 & $1.2 \mathrm{cB}$ & $1.4 \mathrm{dAB}$ & $1.4 \mathrm{bAB}$ \\
\hline $20-30$ & $1.8 \mathrm{aB}$ & $2.0 \mathrm{bAB}$ & $2.0 \mathrm{aAB}$ \\
\hline 25 & $1.5 \mathrm{bC}$ & $2.5 \mathrm{aA}$ & $1.8 \mathrm{aB}$ \\
\hline 30 & $0.8 \mathrm{dC}$ & $1.7 \mathrm{cA}$ & $1.7 \mathrm{bAB}$ \\
\hline
\end{tabular}

Means followed by the same capital letters within each temperature and with the same lowercase letters within each light condition are not different (Tukey test, $p>0.01$ ). 
tion occurred similarly for white and red light at $25^{\circ} \mathrm{C}$. In another study with $C$. jamacaru, the maximum germination for this species was observed at $30{ }^{\circ} \mathrm{C}$ in white light, corresponding to $95.8 \%$ of germination (Meiado et al., 2010). Additionally, for globose cactus Melocactus bahiensis, the highest germination percentage and germination speed index were detected at $25^{\circ} \mathrm{C}$ (Lone et al., 2007).

The highest germination for C.jamacaru seeds at $25{ }^{\circ} \mathrm{C}$ was corroborated with other sudy with the same species performed by Guedes et al. (2009). These authors described that $C$. jamacaru seeds germinated at 25 ${ }^{\circ} \mathrm{C}$ on paper sheets, showing the highest values for GSI and germination percentage at 4 days of imbibition. Conversely, seeds of $C$. jamacaru, Microchanthus flaviflorus and Pilosocereus gounelli had high germination percentages when incubated at $20-30^{\circ} \mathrm{C}$ and $25-35{ }^{\circ} \mathrm{C}$ in photoperiod conditions, whereas - and in agreement with this study - seeds under the darkness condition showed inhibited germination (Veiga-Barbosa et al., 2010). In a recent study of $C$. jamacaru germination under different environmental conditions, no germination in darkness was observed, suggesting that these seeds are positively photoblastic (Meiado et al., 2010). On the other hand, in this study, seeds germinated in darkness, just as other columnar cacti such as Pachycereus pringlei (Nolasco et al., 1997). However, our results suggest that darkness is not appropriate for germinate.
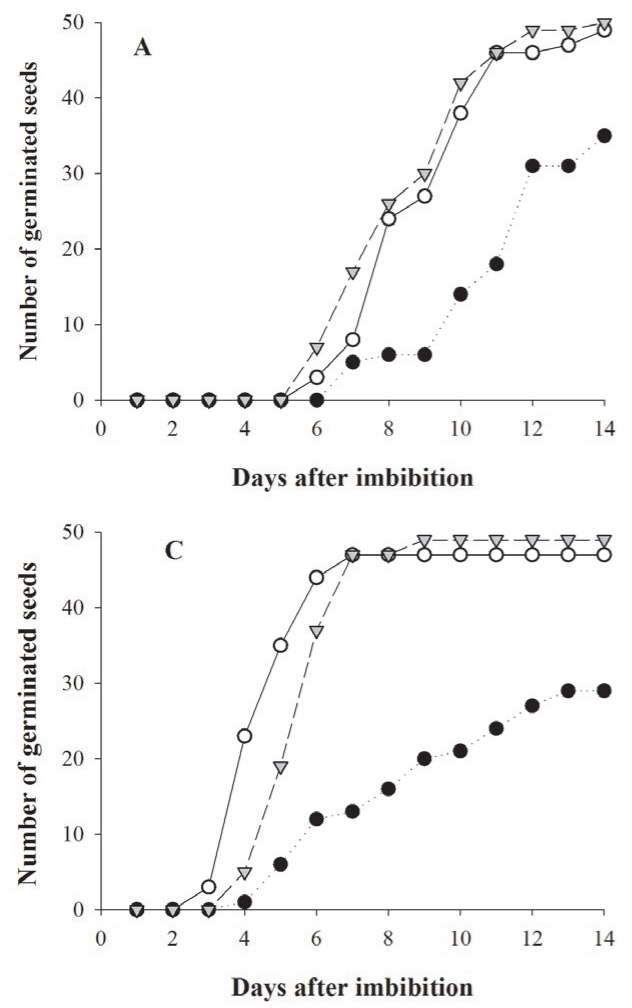

The lowest values of germination average time (GAT) were observed at 25 and $30{ }^{\circ} \mathrm{C}$ associated with white light, whereas the highest GAT values were verified at $20{ }^{\circ} \mathrm{C}$ in darkness. However, the germination of C. jamacaru occurred between 20 and $30{ }^{\circ} \mathrm{C}$ in all light conditions (Table 2A). This result reinforcing that the darkness is not appropriate condition for germination of this cactus, considering that it promoted pronounced increase in GAT, which is related in germination delay.

With respect to temperature, some authors have shown that cactus seed germination usually occurs between 17 and $34{ }^{\circ} \mathrm{C}$, with optimum values around 25 ${ }^{\circ} \mathrm{C}$ (Rojas-Aréchiga et al., 1997; Rojas-Aréchiga and Vásquez-Yanes, 2000). However, for C. jamacaru, it was observed seed germination between 20 and $30{ }^{\circ} \mathrm{C}$, with highest germination at 25 and $30^{\circ} \mathrm{C}$. In contrast to this study, the germination of Hylocereus setaceus occurred at a wide range of temperatures, varying between 15 and $40{ }^{\circ} \mathrm{C}$ under white light (Simão et al., 2007). Interestingly, our results suggest that white and red light at 25 ${ }^{\circ} \mathrm{C}$, followed by the same light conditions at $30{ }^{\circ} \mathrm{C}$, contributed to the highest germination rates for $C$. jamacaru seeds, which were also related to the highest GSI and the lowest GMT values under these conditions.

The highest values for seedling dry mass were observed at $20-30{ }^{\circ} \mathrm{C}$ in white and red light and at $30{ }^{\circ} \mathrm{C}$ in red, whereas the lowest seedling dry mass values were observed at $20^{\circ} \mathrm{C}$ in all light conditions and at $30{ }^{\circ} \mathrm{C}$
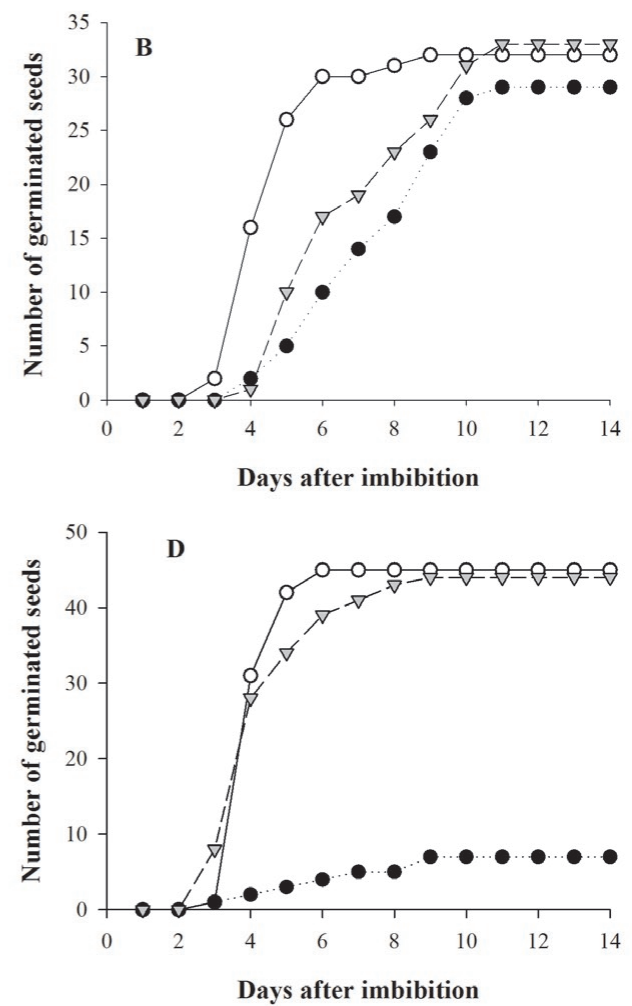

Figure 1 - Germination accumulated frequency of $C$. jamacaru seed germination at 20 (A), $20-30{ }^{\circ} \mathrm{C}$ (alternated) (B), 25 (C) and $30{ }^{\circ} \mathrm{C}(\mathrm{D})$ in white (-o-), darkness $(-\bullet \cdots)$ and red light $(--\nabla-)$. 
in darkness (Table 2B). On the other hand, the highest value of seedling height was observed for germination at $25^{\circ} \mathrm{C}$ in darkness, whereas the lowest height value was verified for $30{ }^{\circ} \mathrm{C}$ in white light, corresponding to only $0.8 \mathrm{~cm}$ (Table $2 \mathrm{C}$ ). This result indicate the light influence on growth parameters, reinforcing the light dependency during C.jamacaru initial seedling development. Similarly, Lone et al. (2007) observed the lowest height value at $20{ }^{\circ} \mathrm{C}$ on paper substrate for Melocactus bahiensis. In a study that also involved $C$. jamacaru, the seedling height was higher at 25 and $30{ }^{\circ} \mathrm{C}$ for seeds germinated in a roll of paper, whereas the seedling dry mass value was higher at 30 and $20-30{ }^{\circ} \mathrm{C}$, regardless of the substrate (Guedes et al., 2009).

Regarding the germination accumulated frequency (GAF), seeds at $20^{\circ} \mathrm{C}$ in white and red light began to germinate simultaneously at $6 \mathrm{DAI}$, reaching the maximum around $12 \mathrm{DAI}$ (Figure $1 \mathrm{~A}$ ). At $20-30{ }^{\circ} \mathrm{C}$, the fastest germination occurred in white light, also showing the maximum value for GAF at 4 DAI, whereas the other conditions were slower (Figure $1 \mathrm{~B}$ ). At $25^{\circ} \mathrm{C}$, seeds in white and red light reached maximum $\% \mathrm{G}$ and GAF in the same period and had the highest number of germinated seeds in these lights, just as at $20{ }^{\circ} \mathrm{C}$. However, under these conditions, seeds at $25{ }^{\circ} \mathrm{C}$ began to germinate at $3 \mathrm{DAI}$, reaching their maximum at 6 DAI (Figure $1 \mathrm{C})$. In relation to $\mathrm{GAF}$ at $30^{\circ}$, a similar behavior to that at $25^{\circ} \mathrm{C}$ was observed in white and red light; however, seeds subjected to darkness showed smaller values of germination accumulated frequency than those in the other lights - the slowest values for all treatments were observed in darkness (Figure 1D). These results also confirm the positive influence of the light presence associated at $25^{\circ} \mathrm{C}$ on $C$. jamacaru seed germination.

The growth parameters were also affected by the interaction between light and temperature, mainly in darkness, when seedlings had the highest height until they became etiolated. In addition, the GAF data confirmed that $C$. jamacaru seed germination is strongly affected by darkness, reinforcing that the absence of light is not appropriate for germination and that the number of germinated seeds is dependent on the light presence, which was mainly observed at $20-30{ }^{\circ} \mathrm{C}$ and $30{ }^{\circ} \mathrm{C}$. Therefore, considering the highest $\% \mathrm{G}$ and GSI associated to the smallest GAT and the fastest germination beginning in white light at 25 or $30^{\circ} \mathrm{C}$, this condition can be considered as the most appropriate for germination tests. Additionally, this information on the best conditions for seed germination and early seedling growth, will facilitate the production of $C$. jamacaru seedlings from seeds and promote the use of this cactus, which has many applications and is an important member of the Caatinga vegetation in Northeast Brazil.

\section{Acknowledgements}

To CNPq for financial support and for the scholarship granted Nara Lídia M. Alencar during her MS studies.

\section{References}

Andrade, C.T.S.; Marques, J.G.W.; Zappi, D.C. 2006. Medicinal use of cactus for farmers. Série Ciências Biológicas (Etnobiologia) 6: 36-42 (in Portuguese, with abstract in English).

Benítez-Rodrígues, J.L.; Orozco-Segovia, A.; Rojas-Aréchiga, M. 2004. Light effects on seed germination of four Mammilaria species from Tehuacán-Cuicatlán Valley, Central México. The Southwestern Naturalist 49: 11-17.

Bewley, J.D.; Black, M. 1994. Seeds: Physiology of Development and Germination. 2ed. Plenum Press, New York, NY, USA.

Bewley, J.D. 1997. Seed germination and dormancy. Plant Cell 9: 1055-1066.

Cavalcanti, N.B.; Resende, G.M. 2004. Consumption of the mandacaru (Cereus jamacaru D.C.) for the goats in the drought period of the semi-arid Pernambuco, Brazil. Revista Caatinga 19: 402-408 (in Portuguese, with abstract in English).

Freitas, N.P.; Takaki, M. 2000. Pelletization of seeds of Raphanus sativus L. cv. redondo gigante with graphite for germination under water stress conditions. Brazilian Archives of Biology and Technology 43: 547-550.

Guedes, R.S.; Alves, E.U.; Gonçalves, E.P.; Bruno, R.L.A.; Braga-Júnior, J.M.; Medeiros, M.S. 2009. Germination of Cereus jamacaru DC. seeds under different substrates and temperatures. Acta Scientiarum. Biological Sciences 31: 159164 (in Portuguese, with abstract in English).

Khera, N.; Singh, R.P. 2005. Germination of some multipurpose tree species in five provenances in response to variation in light, temperature, substrate and water stress. Tropical Ecology 46: 203-217.

Kigel, J. 1995. Seed germination in arid and semi-arid regions. p. 645-646. In: Kigel, J.; Galili, G., eds. Seed development and germination. Marcel Dekker, New York, NY, USA.

Laboriau, L.G. 1983. The Seed Germination. OEA, Washington, DC, USA.

Laboriau, L.G.; Agudo, M. 1987. On the physiology of seed germination in Salvia hispanica L.I. Temperature effects. Annals of the Brazilian Academy of Science 59: 37-56.

Lone, A.B.; Takahashi, L.S.A.; Faria, R.T.; Unemoto, L.K. 2007. Germination of Melocactus bahiensis (Cactaceae) in different substrates and temperatures. Scientia Agraria 8: 365-369 (in Portuguese, with abstract in English).

Lopes, J.C.; Capucho, M.T.; Martins Filho, S.; Repossi, P.A. 2005. The influence of temperature, substrate and light of bertalha seed germination. Revista Brasileira de Sementes 27: 18-24 (in Portuguese, with abstract in English).

Lorenzi, H.; Matos, F.J.A.M. 2002. Medicinal Plants of Brazil: Natives and Exotics. Instituto Plantarum, Nova Odessa, SP, Brazil (in Portuguese).

Maguire, J.D. 1962. Speed of germination: aid in selection and evaluation for seedling emergence and vigor. Crop Science 2: 176-177.

Meiado, M.V.; Albuquerque, L.S.C.; Rocha, E.A. Rójas-Aréchiga, M.; Leal, I.R. 2010. Seed germination responses of Cereus jamacaru DC. ssp. jamacaru (Cactaceae) to environmental factors. Plant Species Biology 25: 120-128. 
Nolasco, H.; Veja-Villasante, F.; Romero-Schimidt, H.L.; DiazRondero, A. 1997. The effects of salinity, acidity, light and temperature on germination of seeds of cardón (Pachycereus pringlei S.Wats.) Briton \& Rose, Cactaceae). Journal of Arid Environments 33: 87-94.

Ortega-Baes, P.; Rojas-Aréchiga, M. 2007. Seed germination of Trichocereus terscheckii (Cactaceae): light, temperature and gibberellic acid effects. Journal of Arid Environments 69: 169176.

Rojas-Aréchiga, M.; Orozco-Segovia, A.; Vázquez-Yanes, C. 1997. Effect of light on germination of seven species of cacti from Zapotitlán Valley in Puebla, México. Journal of Arid Environments 36: 571-578.
Rojas-Aréchiga, M.; Vásquez-Yanes, C. 2000. Cactus seed germination: a review. Journal of Arid Environments 44: 85104.

Simão, E.; Socolowski, F.; Massanori, T. 2007. The epiphytic Cactaceae Hylocereus setaceus (Salma-Dick ex DC.) ralf bauer seed germination is controlled by light and temperature. Brazilian Archives of Biology and Technology 50: 655-662.

Veiga-Barbosa, L.; Gonzalez-Benito, M.E.; Assis, J.G.A.; PérezGarcia, F. 2010. Germination and cryopreservation of several cactus species from ND Brazil. Seed Science Technology 38: 218-224. 